\title{
The Influence of Personal Factors on the Process of Facilitative Interaction
}

\section{Вплив особистісних чинників на процес фасилітативної взаємодії}

\author{
Nataliia Khupavtseva \\ Ph.D. in Psychology, Assistant Professor, Rivne State Univer- \\ sity of the Humanities, Rivne (Ukraine) \\ ORCID ID: https://orcid.org/0000-0002-8883-7686 \\ Researcher ID: AAC-2156-2019 \\ E-mail: natalahupavceva@gmail.com

\section{Наталія Хупавцева} \\ Кандидат психологічних наук, доцент, Рівненський дер- \\ жавний гуманітарний університет, м. Рівне (Україна)
}

\section{ABSTRACT}

The purpose of the article is to reveal the personal factors of facilitative interaction that most effectively influence on the successful realization of the subjects' activity in general and cognitive activity in particular.

Methods of the research. The following theoretical methods of the research were used to solve the tasks formulated in the article: a categorical method, structural and functional methods, the methods of the analysis, systematization, modeling, generalization.

The results of the research. It has been proved that some misunderstandings in the perception of a task or a problem were a major factor affecting facilitative interaction. Another factor that may indirectly cause the effect of the presence of observers is the state of arousal in which a person is performing this task or

Address for correspondence, e-mail: kpnu_lab_ps@ukr.net Copyright: (C) Khupavtseva Nataliia

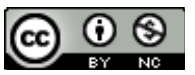

The article is licensed under CC BY-NC 4.0 International

(https://creativecommons.org/licenses/by-nc/4.0/)

(C) Khupavtseva Nataliia

DOI (article): https://doi.org/10.32626/2227-6246.2020-49.363-385 
problem at the time. It was noted that a sufficiently strong level of excitation decreases substantially at the presence of observers, and a weak level - in a case of absence of observers. Consequently, the presence of observers generally facilitates a simple task and impairs the resolution of a complex, incomprehensible or intangible subject. Another factor that needs to be taken into account is the relationship between the disturbance caused by the presence of observers or participants in a joint activity and the performance of that activity, which requires a clear coordination of personal movements or efforts.

The skills of "emotional teaching" are defined, which can be called the techniques of pedagogical facilitation (based on empathy, respect, sincerity): teachers ignore the emotional manifestations of their students, thereby causing their aggression; teachers' statements, as a rule, do not correspond to feelings, they are not sincere, except in some cases when they condemn and blame the students; the teacher responds not to the true feelings of each student, but to those that he / she himself / herself imparts to him / her, in his / her own statements he / she only sometimes is sincere, but tries not to express positive emotions; the teacher responds only to the superficial feelings of the student, but does it quite accurately and often he / she is not afraid to express both positive and negative feelings, but does not confirm it aloud, expresses his / her feelings in a non-verbal way; the teacher responds to the hidden, deep feelings of each student, helps students to understand why they feel in such a way, gives a sincere reaction at both verbal and non-verbal levels, both positive and negative, while negative assessment does not diminish the student's self-esteem in any way.

Conclusions. The author of the article proposed the personal factors which in a great degree determined the effectiveness of facilitative interaction: a moderate level of anxiety of the person; incomplete (partial) understanding of the teacher's task or problem; the average level of nervous excitement that facilitates the acceptance of facilitative interaction in the process of performing the activity; the emotional presentation of the context of a task or a problem or the emotional teaching of educational material in a case of pedagogical facilitation; compression of the sphere of authoritative influence on pupils; mutual understanding of participants of the facilitative interaction; mutual acceptance of individual psychological qualities of each other; abilities to put oneself on the place of others, to identify himself / herself with them; to actualize trust of participants of facilitative interaction; updating the subjectivity of the person (in this case, the most important are subjective parameters of the teacher's person, which are necessarily taken into account by pupils or students, (C) Khupavtseva Nataliia

DOI (article): https://doi.org/10.32626/2227-6246.2020-49.363-385 
and they play the important role); the formation of significant psychological status of the personality.

Key words: facilitative interaction, personal factors, anxiety, understanding of a task or a problem, nervous excitement, emotional presentation of the context, individual psychological qualities.

\section{Вступ}

Психологічних досліджень фасилітативної взаємодії не так багато в науковій теоретичній парадигмі. Сучасні дослідження свідчать про те, що форма оцінки істотно впливає на ефективність фасилітації. У дослідженнях I. М. Фейгенберга (Фейгенберг, 1981) студенти опановували складним психомоторним навиком за умов дотримання: безпосередньої оцінки діяльності, оцінки результату діяльності (маємо на увазі непряму оцінку), діяльність без будь-якої оцінки. Результати підтвердили припущення К. Роджерса (Роджерс, 1984: 235) щодо фасилітації як результату набутої реакції в ситуації оцінювання. Дослідження також свідчило про те, що безпосередня оцінка (у разі здійснення спостереження за процесом діяльності) більшою мірою здійснювала вплив на особистість, ніж непряма оцінка, за умов якої учасники спільної діяльності могли оцінювати лише кінцевий результат, а не саму по собі діяльність.

Цей висновок можна підтвердити деякими прикладами з повсякденного життя. Наприклад, учень завжди відчуває занепокоєння, якщо вчитель постійно слідкує за тим, як школяр виконує завдання, але відчуває себе набагато спокійніше, виконуючи роботу наодинці, й потім здає її вчителеві у вигляді самостійної роботи або реферування. Емпіричні дослідження також підтвердили той факт, що соціальне збудження сприяє актуалізації домінуючої реакції, незалежно від того, чи вона є адекватною або ні. Окрім того, А. Б. Орлов (Орлов, 1994: 7) з'ясував, що студентам університету в присутності інших людей потрібно набагато менше часу для ви-

(C) Khupavtseva Nataliia

DOI (article): https://doi.org/10.32626/2227-6246.2020-49.363-385 
вчення досить простого лабіринту і більше часу - для вивчення складного.

Л. К. Малштейн зі співробітниками виявив, що успішні гравці в більярд зі студентського союзу Віргінського політехнічного інституту (ті, хто потрапив до вищої ліги у $71 \%$ випадків за умов прихованого спостереження) грали набагато краще (81\% успішних ігор), коли четверо або більше спостерігачів приходили подивитися на їхню гру. Цікавим також був результат у тих спортсменів, які грали недостатньою мірою добре (у котрих, як правило, результативність становила $36 \%$ ), які за умов публічного виступу грали набагато гірше (25\% успішних ігор) (Малштейн, 1991: 43).

Спортсмени, як правило, досягають вищих результатів, граючи «вдома», i нерідко їхні результати поліпшуються завдяки енергійній підтримці уболівальників. Дослідження понад 80000 матчів в університетському і професійному спорті Канади, Англії та США виявило, що команди виграють у середньому на своєму полі 6 ігор із 10 (дещо менше (5 ігор із 10) у бейсболі й американському футболі, дещо більше (8 ігор із 10) у баскетболі та європейському футболі). Перевага гри «вдома» має місце завдяки кращому знайомству гравців із місцевими умовами, відсутності переїздів, які втомлюють спортсменів, почуттю домінування, що виникає завдяки контролю своєї території, а також завдяки актуалізації командної ідентичності під впливом привітань та оплесків «своїх» уболівальників (Малштейн, 1991: 47). Відтак, у цьому випадку фасилітативний вплив здійснює оточуючий простір.

Отже, роботи зарубіжних авторів довели, що спільна діяльність сприяє успішному виконанню завдань, які вимагають невеликого обсягу часу для навчання суб'єктів соціальної взаємодії. Цей висновок підтверджує гіпотезу R. Zajonc i S. Sales, які виявили, що участь у спільній діяльності підвищує швидкість реакції та досягнення успіху у виконан(C) Khupavtseva Nataliia

DOI (article): https://doi.org/10.32626/2227-6246.2020-49.363-385 
DOI: https://doi.org/10.32626/2227-6246.2020-49 2020. випУСК 49

ні простих психомоторних завдань (Zajonc \& Sales, 1966: 160-168).

Проте, до сих пір питання психологічних чинників, що дають підстави досить точно стверджувати, як саме присутність інших, сторонніх людей, які спостерігають за процесом виконання певною особистістю пізнавальної діяльності, впливає на результат цієї діяльності. Психологи стверджують, що такими психологічними характеристиками можуть бути особистісні властивості та якості індивіда, особливості конкретної ситуації й виконання завдання або задачі.

Тому мета нашої статті - розкрити особистісні чинники фасилітативної взаємодії, які найбільшою мірою ефективно впливають на успішність реалізації пізнавальної діяльності.

\section{Завдання статті}

1. Проаналізувати особистісні чинники, окреслити їх вплив на фасилітативну взаємодію загалом і на педагогічну фасилітацію зокрема.

2. Описати, яким чином рівень тривожності людини зумовлює результат фасилітативної взаємодії.

3. Розглянути питання впливу присутності сторонніх осіб на залежність «збудження - виконання діяльності» .

4. Проаналізувати питання впливу особистісних чинників на процес фасилітативної взаємодії під час освітнього процесу.

\section{Методи дослідження}

Для розв'язання поставлених у роботі завдань використано такі теоретичні методи дослідження: категоріальний, структурно-функціональний, аналіз, систематизація, моделювання, узагальнення.

\section{Результати та дискусії}

Схарактеризуємо особистісні чинники. На особливу увагу заслуговує тривожність як властивість людини, що акту(c) Khupavtseva Nataliia

DOI (article): https://doi.org/10.32626/2227-6246.2020-49.363-385 
DOI: https://doi.org/10.32626/2227-6246.2020-49

алізує ї̈ особистісну диспозицію. Зокрема, Т. Г. Браже виявила, що у високотривожних дітей темп виконання діяльності, як правило, знижується, а в низькотривожних - зростає у присутності сторонніх спостерігачів. Також Т. Г. Браже припустила, що присутність іншої людини сприймається високотривожними дітьми як ситуація оцінки, при цьому тривога суттєво заважає працювати. Для низькотривожних дітей спостерігач постає як стимул виконання успішнішої діяльності (Браже, 1995: 69). У дослідженнях В. К. Вілюнаса було отримано аналогічні результати. Присутність спостерігача (або спостерігачів) суттєво заважала високо- і середньою мірою тривожним жінкам, але не заважала низькотривожним (Вилюнас, 1990).

Однак в емпіричних дослідженнях М. I. Єрецького (Ерецкий, 1988) не було виявлено, що рівень тривожності людини опосередковує вплив ефекту присутності стороннього спостерігача на виконання психомоторного завдання. Різниця в результатах може бути пов'язана з різними шкалами особистісної тривожності, а також із різницею у вибірках респондентів і типах завдань. У всякому разі, слід було здійснити додаткові емпіричні дослідження, щоб зрозуміти, як саме тривожність впливає на поведінку людини в присутності інших людей. 3 ефектом фасилітації, безсумнівно, щільно пов'язаний і рівень підготовленості людини. Так, К. Інгенкамп (Ингенкамп, 1991) припустив, що більш підготовленим виконавцям присутність сторонніх осіб заважає, є меншою мірою підготовленим, навпаки, допомагає. Останній висновок великою мірою суперечить гіпотезі, сформульованій R. Zajonc (Zajonc, 1965).

У сучасних нейропсихолінгвістичних дослідженнях (Лернер, 1996: 7-11; Максименко, Ткач, Литвинчук \& Онуфрієва, 2019: 246-264) виявлено, що діяльність людей із повільним і середнім темпами виконання завдань відповідає гіпотезі Р. Зайонца, але на швидкість присутність інших не впливає жодним чином. Емпіричні дослідження Р. Мар(C) Khupavtseva Nataliia

DOI (article): https://doi.org/10.32626/2227-6246.2020-49.363-385 
тене були пов'язані з рівнем підготовленості осіб до виконання одного виду діяльності, зокрема, в них порівнювалися спортсмени і люди, які не займаються спортом. Усім їм пропонувалося виконати завдання щодо втримання рівноваги в присутності спостерігачів. Виявилося, що люди, які не займалися професійним спортом, виконували завдання в присутності сторонніх набагато краще, ніж спортсмени (Мартене, 1979).

Останне ми можемо пояснити так. Спортсмени, добре підготовлені в одному виді спорту, необов'язково мають характеризуватися високою здатністю й щодо виконання нових, більшою мірою складних для них рухів. Але, з іншого боку, навряд чи варто було очікувати, що спортсмени передбачали, що від них очікують деякої переваги у виконанні нових завдань i, отже, в присутності аудиторії, яка виконувала роль експертів, гірше виступали люди, які не займаються спортом, від яких експерти не очікували успіху. Цей взаємозв'язок рівня підготовленості й успішності виконання завдання в присутності спостерігачів вимагав здійснення подальших емпіричних досліджень.

Певні непорозуміння у сприйнятті завдання або задачі є основним чинником, який впливає на фасилітативну взаємодію. Іншим чинником, який може опосередковано зумовити ефект присутності сторонніх спостерігачів, є стан збудження, у якому перебуває людина на момент виконання певного завдання або задачі. Якщо за домінувальну реакцію прийняти виконання адекватної дії, то, грунтуючись на гіпотезі фасилітації, можна передбачити, що підвищення рівня збудження, викликане присутністю сторонніх осіб, сприятиме виконанню поставленого завдання або задачі.

Також є деякі підстави вважати, що за умов опанування завданням й оволодіння навчальним матеріалом збудження, яке постійно зростатиме, не буде до безкінечності сприяти поліпшенню виконання завдання або задачі. Коли людина досягає винятково високого рівня збудження, процеси (C) Khupavtseva Nataliia DOI (article): https://doi.org/10.32626/2227-6246.2020-49.363-385 
DOI: https://doi.org/10.32626/2227-6246.2020-49 2020. випуск 49

сприйняття і регуляції рухів загалом порушуються. Тому можна припустити, що помірне підвищення збудження суттєво полегшить виконання добре вивченого завдання, але безперервне зростання збудження, врешті-решт, погіршить його. Ця залежність, експлікована в гіпотезі інвертованої U-подібної кривої, або в законі Єркса - Додсона, є однією з найвідоміших гіпотез у психології.

На взаємозв'язок «збудження - виконання діяльності» впливає ще й та обставина, чи є домінуюча реакція правильною або неправильною, а також особистісні та ситуативні чинники, особливості формулювання завдання і передумови, які викликають збудження.

Отже, психологи зіштовхнулися з необхідністю розглянути питання впливу присутності сторонніх осіб на залежність «збудження - виконання діяльності». Отримані дані дали підстави припустити, що мало збуджена людина виконуватиме завдання відповідно до гіпотези R. Zajonc (Zajonc, 1965: 274), а якщо особистість збуджена помірною мірою то ефективність виконання завдання буде набагато вища за умов присутності сторонніх. Але якщо людина із самого початку досить сильно збуджена, то присутність сторонніх ще сильніше збуджує їі, й вона починає виконувати завдання все гірше і гірше. Тому ці дані дозволяють припустити, що якщо людина великою мірою збуджена, то присутність сторонніх може діяти на неї заспокійливо і не посилювати, а зменшувати, рівень збудження (Мескон, 1994).

Отже, досить сильний рівень збудження суттєво знижується в присутності сторонніх осіб, а слабкий рівень, навпаки, посилюється. Присутність сторонніх, як правило, полегшує виконання простого завдання і погіршує розв'язання складного, не зрозумілого або не опанованого суб'єктом. Інший чинник, який треба брати до уваги, - це взаємозв'язок між порушенням, викликаним присутністю спостерігачів або учасників спільної діяльності, й виконанням цієї діяльC Khupavtseva Nataliia

DOI (article): https://doi.org/10.32626/2227-6246.2020-49.363-385 
ності, що вимагає чіткої координації рухів або неабияких зусиль із боку особистості.

Проаналізуємо питання впливу особистісних чинників на процес фасилітативної взаємодії під час освітнього процесу. Впродовж педагогічної фасилітації К. М. Левітан пропонує вчителям та учням усе робити разом. Учений пропонує розрізняти вчителя (який займається освітою своїх учнів, «підтягуванням» їх до певного заданого рівня) і педагога (який допомагає учням у їх власній навчальній активності). Автор доводить, що треба бути Педагогом, а не «Вчителем» . Ця на перший погляд недостатньою мірою важлива роль педагога в реальному процесі шкільного навчання вимагає величезної самоповаги, неабиякого особистісного потенціалу, бездоганних навичок конструктивної взаємодії. Педагог як професіонал характеризується особливою емпатійністю: він бачить і чує всі негаразди, помилки й невдачі, вміє допомагати тільки тоді, коли його допомога дійсно є необхідною (Левитан, 1991). Справжній педагог ніколи не виявляє ініціативу самостійно, навіть не завжди привертає до себе увагу, проте він уміє робити все таким чином, щоб учні самі проявляли активність. Про це говорить і М. В. Кларін, коли критикує традиційний «школярський» підхід до навчання за типом простої передачі інформації. Учений наголошує на тому, що слід зробити процес навчання шляхом особистісного зростання. За цим підходом, учителеві більшою мірою слід бути фасилітатором (людиною, яка суттєво полегшує ініціативу й особистісну взаємодію учнів між собою), ніж власне ініціатором особистісного розвитку, варто більше підтримувати підопічних осіб, ніж оцінювати їх (Кларин, 1989).

M. I. Махмутов також вважає, що педагогу, який створює найбільшою мірою позитивні умови для особистісного зростання своїх учнів і себе самого, досить важливо оволодіти навичками «емотивного викладання». Крім власне викладання свого предмета, педагогові слід актуалізувати емоційні прояви (свої власні й учнів) як такі, що містять (C) Khupavtseva Nataliia

DOI (article): https://doi.org/10.32626/2227-6246.2020-49.363-385 
DOI: https://doi.org/10.32626/2227-6246.2020-49 2020. випуск 49 особливий зміст. Педагог, байдужий до почуттів і переживань учнів, завжди стикається з труднощами у процесі викладання навчальних предметів. Чим досвідченішим є вчитель, тим більше уваги на уроці він приділяє емоційному настрою в класі загалом і кожного окремого учня зокрема. На думку М. I. Махмутова, існує чотири навички «емотивного викладання», які можна назвати техніками педагогічної фасилітації (базуються на емпатії, повазі, щирості):

- педагог ігнорує емоційні прояви своїх учнів, викликаючи тим самим їхню агресію; висловлювання педагога, як правило, не відповідають почуттям, вони є нещирими, за винятком окремих випадків, коли вони засуджують і звинувачують школярів;

- педагог реагує не на справжні почуття учня, а на ті, які він сам йому навіює; у власних висловлюваннях він лише інколи буває щирим, але позитивні емоції намагається не виявляти;

- педагог реагує лише на поверхневі почуття учня, але робить це досить точно і часто; не боїться висловлювати як позитивні, так і негативні почуття, але не підтверджує це вголос, висловлює свої почуття у невербальний спосіб;

- педагог реагує на приховані, глибинні почуття кожного учня, тим самим допомагаючи школярам усвідомити, чому вони відчувають те, що саме вони відчувають; дає щиру реакцію як на вербальному, так і на невербальному рівні, як позитивну, так і негативну оцінку, при цьому негативна оцінка жодним чином не принижує почуття власної гідності учня (Махмутов, 1972).

А. Я. Наїн зазначає, що фасилітація - це зміна ефективності діяльності учня впродовж контакту з учителем або з іншими школярами. Навіть пасивна присутність педагога в класі великою мірою активізує учнів, спрямовує їх діяльність у потрібному напрямку, стабілізуе їі поза цілеспрямованих дій із боку педагога. Однак, феномен фасилітації має неабиякий вплив тільки в тому випадку, якщо педагог є ав(C) Khupavtseva Nataliia

DOI (article): https://doi.org/10.32626/2227-6246.2020-49.363-385 
торитетним, референтним, визнаним. Тоді внаслідок педагогічної взаємодії виникають різні психологічні новоутворення особистісного та міжособистісного характеру, які прийнято називати «змінами», або «феноменами» (Наин, 1990).

Феномен авторитету педагога має неабияке значення в реалізації стратегій педагогічної взаємодії, які він використовує. Спостереження за навчальною діяльністю свідчать про те, що педагог може бути досить-таки авторитетною особою для учнів будь-якого віку, але підстави для визнання його авторитету різноманітні. Для молодших школярів учитель є авторитетом з огляду на авторитетність своєї рольової позиції. Стосовно цього віку школярів можна говорити, скоріше за все, щодо авторитету ролі, ніж авторитету особистості. При цьому за вчителем визнається право на прийняття відповідальних рішень щодо певної ситуації як стосовно конкретного учня, так і щодо класу загалом, як у навчальній, так і в інших видах діяльності.

Для дитини лише авторитету ролі вчителя недостатньо. Проте, в ситуаціях, значущих як для класу, так і для вчителя, домінуючим залишається право на прийняття відповідального рішення. У ситуаціях, які є особистісно значущими для дитини, особливо в умовах позанавчальної діяльності, така довіра авансується вчителеві меншою мірою. Таке компресування сфери авторитетного впливу, визнання авторитету лише в одній або деяких сферах навчальної взаємодії називають «специфікацією авторитету» педагога.

Якщо дитина визнає за вчителем право на прийняття відповідального рішення і в особистісно значущій ситуації, то такий стан речей є проявом справжнього авторитету особистості педагога. У старшокласників великою мірою посилюється авторитет учителя за рахунок зменшення орієнтації на роль. Учителі часто стають референтними у зв'язку з цілковитим визнанням їх особистості. Водночас авторитет педагога актуалізується тільки як реакція на його шанобливе ставлення до учнів.

(C) Khupavtseva Nataliia

DOI (article): https://doi.org/10.32626/2227-6246.2020-49.363-385 
Однією з детермінант фасилітативної взаємодії є взаєморозуміння, яке визначається як деяка стала система почуттів і взаємостосунків, що дає змогу великою мірою узгоджено досягати мети спільної діяльності або спілкування і максимально сприяє дотриманню довіри й інтересів, надаючи можливості для саморозкриття здатності кожного учасника цієї взаємодії. Фасилітативне взаєморозуміння в окреслений спосіб забезпечує такий рівень «спільності», коли між учасниками педагогічного процесу немає авторитарного домінування, емоційної напруги, недовіри і незацікавленості всім, що відбувається у цьому процесі.

Однією з головних умов виникнення феномену взаєморозуміння є взаємне прийняття індивідуальних психологічних властивостей один одного, вміння поставити себе на місце інших, ідентифікуватися 3 ними. Взаєморозуміння $є$ наслідком гуманістичної орієнтації педагогів, які сприймають успіхи учнів і цілі їх навчальної діяльності як свої власні.

У процесі фасилітативної взаємодії феномен довіри є близьким за своїми характеристиками до феномену взаєморозуміння. Довіра є почуттям відкритості світу людей, явищ, процесів. Довіра не означає дещо прийняти на віру, не усвідомлюючи глибинної сутності явища. Довіра може бути інтуїтивною або усвідомленою, безпосередньою чи опосередкованою. Відсутність довіри, відчуження від дитини є однією з головних деструктивних причин, що затримує розвиток особистості. Діти відчувають гостру потребу в тому, щоб їм довіряли як авторитетні значущі однолітки, так і дорослі люди, педагоги тощо.

У процесі розвитку дитини відбувається становлення ii базової довіри до всього світу. Світ має опановувати свідомістю дитини не завдяки певним загрозливим поштовхам, а таким, які задовольняють дитину, приносять їй радість. Завжди слід звертати увагу на досягнення дитини, щоб вона накопичувала досвід позитивної оцінки, вчилася рефлексувати. Позитивний відгук, похвала, прийняття досягнень як (C) Khupavtseva Nataliia

DOI (article): https://doi.org/10.32626/2227-6246.2020-49.363-385 
особистісно значущих моментів суттєво підвищують, розвивають і підтримують самооцінку та самоповагу дитини.

Із самого раннього віку дитина відчуває ставлення інших людей, яке для неї набуває неабиякої значущості. Тому вже з дошкільного віку закладаються моделі довірчого, гуманного ставлення до інших людей. Особистісний розвиток дитини є наслідком турботи щодо неї, розуміння їі. Дитина повинна завжди відчувати, як дорослі переживають за неї, щоб навчитися думати і піклуватися про інших. Отже, особистість іншого має стати частиною життєвого світу дитини, а дитина має навчитися бачити в іншій людині особистість. Тільки за таких умов дитина повною мірою сприйматиме значущість фасилітативної взаємодії.

У фасилітативній взаємодії, на нашу думку, виявляється феномен «відображеної суб’єктивності». У його виникненні неабияку роль відіграють суб'єктивні параметри особистості педагога, які осмислюються й обов'язково враховуються учнями. 3 психологічного образу вчителя ці параметри експлікуються на особистісну сферу учнів. Образ учителя може бути як реальним, так і уявним. У деяких випадках уявний образ є, разом із тим, реальним за ефективністю впливу, як, до речі, й реальний учитель. У такій фасилітативній взаємодії відбувається трансляція суб’єктності педагога, а саме його здатності здійснювати смислові перетворення у структурі особистості учнів.

Одним зі значущих конструктивних феноменів фасилітативної взаємодії є психологічний статус особистості, без набуття якого не може існувати процес активного прогресивного розвитку і саморозвитку особистості. Психологічний статус характеризує не тільки реальне місце учня в системі міжособистісних взаємостосунків, але й позицію в клаci, сім’ї, групах однолітків, яку він відносить до самого себе. Потреба в побудові себе як особистості, в самовдосконаленні тощо не виникає спонтанно - вона становиться у процесі фасилітативної взаємодії. Саме педагогічний вплив дає змогу (C) Khupavtseva Nataliia DOI (article): https://doi.org/10.32626/2227-6246.2020-49.363-385 
учневі усвідомити розбіжність «Я-реального» та «Я-ідеального», без чого не може відбутися особистісний розвиток. Фасилітативна взаємодія виконує функцію не тільки допомоги і захисту дитини від невпевненості, страху невиконання навчальних завдань і задач, а й допомагає утвердженню статусу учня, формуванню його рольової позиції. Фасилітативна взаємодія передбачає неабияку увагу, надану людині в ситуації, коли вона є ще об’єктивно неуспішною; ця увага може виявлятися у формі або прямого висловлювання, або імпліцитних фреймів чи скриптів. Фасилітативна взаємодія також передбачає реалізацію школярем впливів на іншу особистість. Своєю чергою, здійснюючи фасилітативний вплив на учня, педагог звертається до його особистості незалежно від його невдач і успіхів, помилок і досягнень. Для ефективної фасилітативної взаємодії, відтак, визначальним стає безумовне прийняття іншого, причому неважливими є кінцеві результати фасилітативної взаємодії, оцінки з навчального предмета, зовнішні риси. Фасилітативно взаємодіяти слід із кожною дитиною, і для цього потрібно лише постійно бачити й актуалізувати увагу на її сильних сторонах.

Моделі фасилітативної взаємодії не створюються самі по собі. Вони мають соціокультурну значущість, відображають специфіку життєвого шляху педагога, його вікові, особистісні характеристики, а також рівень професійної компетентності й педагогічної творчості.

Проаналізовані феномени фасилітативної взаємодії зумовлюють необхідність відповідності особливостей організації цієї взаємодії психологічним характеристикам учасників навчального процесу. Для цього педагог повинен опанувати прийомами психологічної діагностики, корекції, консультування. У цьому випадку педагогічні дії вирізнятимуться не пошуковим або орієнтовним характером, а виваженим, науково обгрунтованим тощо.

В. Т. Кудрявцев наполягав на необхідності врахування таких підходів для створення на заняттях середовища, (C) Khupavtseva Nataliia

DOI (article): https://doi.org/10.32626/2227-6246.2020-49.363-385 
оптимального для розв'язання навчальних завдань на основі співпраці педагога з учнями:

- інтерактивного, заснованого на свободі тих, хто навчається; у цьому плані важливим є зворотний зв'язок у системі «учитель - учень», організація продуктивного спілкування вчителя й учнів, урахування реакцій учнів і оптимізація освітнього середовища з метою підвищення ефективності процесу навчання. До інтерактивних методів навчання відносяться, зокрема, навчальна дискусія, евристична бесіда, диспут, різноманітні за формою рольові й імітаційні ігри, що моделюють ситуації, які виявляються у процесі розв’язання школярами проблем, завдань і задач;

- фасилітативного, який передбачає створення на заняттях середовища, оптимального для розв'язання завдань і задач на основі співпраці педагога з учнями, прийняття й постійної підтримки учнів, віри в їх здатності, можливості, на основі взаємоповаги та довіри. Фасилітативний підхід сприяє розвитку активної особистісної позиції, найповнішому задоволенню пізнавальних і творчих потреб, тобто, i самореалізації учнів (Кудрявцев, 1991).

Отже, на нашу думку, можна виокремити такі особистісні чинники, які зумовлюють ефективність здійснення фасилітативної взаємодії (рис. 1):

- помірний рівень тривожності особистості;

- неповне (часткове) розуміння сформульованого вчителем завдання або задачі;

- середній рівень нервового збудження, який сприяє прийняттю фасилітативної взаємодії у процесі виконання діяльності;

- емотивна презентація контексту завдання або задачі чи емотивне викладання навчального матеріалу в разі здійснення педагогічної фасилітації;

- компресування сфери авторитетного впливу дорослих;

- взаєморозуміння учасників фасилітативної взаємодії;

(C) Khupavtseva Nataliia

DOI (article): https://doi.org/10.32626/2227-6246.2020-49.363-385 
DOI: https://doi.org/10.32626/2227-6246.2020-49

2020. ВиПУСК 49

- взаємне прийняття індивідуальних психологічних властивостей один одного;

- уміння поставити себе на місце інших, ідентифікуватися з ними;

- довіра до учасників фасилітативної взаємодії;

- актуалізація суб'єктності особистості (у цьому випадку неабияку роль відіграють суб'єктивні параметри особистості педагога, які осмислюються й обов'язково враховуються учнями);

- формування значущого психологічного статусу особистості.

\begin{tabular}{|c|c|c|c|c|c|c|c|c|c|c|}
\hline & CH & & & ЮЮ & еК & :ТЬ & еннs & & 0 & одії \\
\hline$\nabla$ & $\downarrow$ & $\downarrow$ & $\downarrow$ & $\frac{1}{t}$ & $\downarrow$ & $\downarrow$ & $\frac{1}{7}$ & $\downarrow$ & $\frac{1}{t}$ & 7 \\
\hline 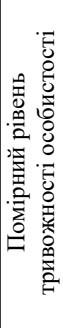 & 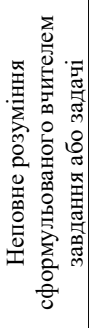 & 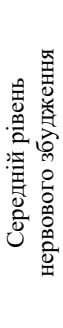 & 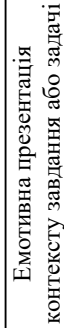 & 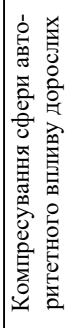 & 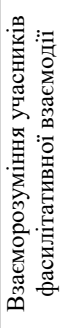 & 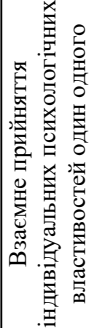 & 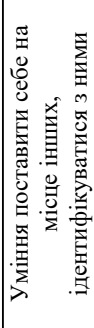 & 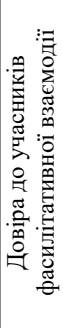 & 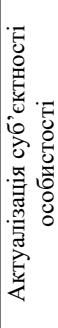 & 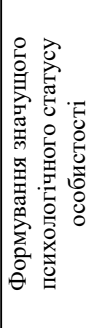 \\
\hline
\end{tabular}

Puc. 1. Особистісні чинники, що зумовлюють ефективність здійснення фасилітативної взаємодії

\section{Висновки}

Педагог повинен допомагати учням розв'язувати не тільки навчальні, а й особистісно значущі завдання; у цьому плані й має прийти на допомогу фасилітативна взаємодія. Однак, у реаліях педагогічного процесу успішність школяра $\epsilon$ основним показником його невдач $\mathrm{i}$ досягнень упродовж усього часу перебування в школі. Високий рівень успішності зазвичай асоціюється у батьків із загальним благополуччям учня, а низька успішність сприймається як показник неабияких труднощів, неблагополуччя школяра. Останнє (C) Khupavtseva Nataliia

DOI (article): https://doi.org/10.32626/2227-6246.2020-49.363-385 
суттєво спотворює й ускладнює становище учня, адже сукупність психологічних чинників, що впливають на організацію фасилітативної взаємодії, нерідко підміняється одним із них. При цьому такі характеристики школяра, як ділова та колективістська спрямованість, високорозвинені здібності, зовнішність, особистісні властивості, вік, товариськість, готовність допомогти товаришеві, манери поведінки тощо, залишаються не врахованими або не прийнятими до уваги.

Отже, теоретичний аналіз наукової літератури переконливо свідчить про те, що фасилітативна взаємодія дійсно значною мірою полегшує, сприяє, стимулює організацію навчального процесу в сучасній середній школі, активізує особистісний розвиток учнів, що щільно пов'язано з наданням учням більшої свободи і відповідальності, із загальною парадигмою гуманізації міжособистісного спілкування в школі.

\section{Література}

Браже Т. Г. Современная аттестация учителей: цели и тенденции. Педагогика. 1995. № 3. С. 69-73.

Вилюнас В. К. Психологические механизмы мотивации. Москва : Изд-во Московского университета, 1990. 183 с.

Ерецкий М. И. Совершенствование обучения в техникуме. Москва : Высшая школа, 1988. 264 с.

Ингенкамп К. Педагогическая диагностика. Москва : Педагогика, 1991. $240 \mathrm{c}$.

Кларин М. В. Педагогическая технология в учебном процессе: анализ зарубежного опыта. Москва : Знание, 1989. 80 с.

Кудрявцев В. Т. Проблемное обучение: истоки, сущность, структура, перспективы. Москва : Знание, 1991. 79 с.

Левитан К. М. Личность педагога: становление и развитие. Саратов : Изд-во Саратовского университета, 1991. 168 с.

Лернер И. Я. Развивающее обучение с дидактических позиций. Педагогика. 1996. № 2. С. 7-11.

Максименко С., Ткач Б., Литвинчук Л., Онуфрієва Л. Нейропсихолінгвістичне дослідження політичних гасел із зовнішньої реклами. Psycholinguistics. Психолінгвістика. Психолингвистика. 2019. № 26 (1). C. 246-264. URL : https://psycholing-journal.com/ index.php/journal/article/view/715.

(C) Khupavtseva Nataliia

DOI (article): https://doi.org/10.32626/2227-6246.2020-49.363-385 
DOI: https://doi.org/10.32626/2227-6246.2020-49 2020. випуск 49

Малштейн Л. К. Формы активного обучения. Свердловск : СИПИ, 1991. $76 \mathrm{c.}$

Мартене Р. Социальная психология и спорт. Москва : Физкультура и спорт, 1979. 176 с.

Махмутов М. И. Теория и практика проблемного обучения. Казань : Таткнигоиздат, 1972. 351 с.

Мескон М. Х. Основы менеджмента. Москва : Дело ЛТД, 1994. 702 с.

Наин А. Я. Обучение как управляемый процесс. Челябинск : Челябинский государственный институт физической культуры, 1990. 63 с.

Орлов А. Б. Фасилитатор и группа: от персонального к трансперсональному общению. Московский психотерапевтический журнал. 1994. № 2. С. 8-13.

Роджерс К. Р. Эмпатия. Психология эмоций. Тексты. Москва : МГУ, 1984. С. 234-238.

Фейгенберг И. М. Проблемные ситуации и развитие активности личности. Москва : Знание, 1981. 48 с.

Zajonc, R., \& Sales, S. (1966). Social facilitation of dominant and subordinate responses. Journal of Experimental Social Psychology, 2, 160-168.

Zajonc, R. (1965). Social facilitation. New York : Science. P. 269-274.

\section{References}

Brazhe, T. G. (1995). Sovremennaia attestatsiia uchitelei: tseli i tendentsii [Contemporary certification of teachers: goals and trends]. Pedagogika - Pedagogics, 3, 69-73 [in Russian].

Viliunas, V. K. (1990). Psikhologicheskiie mekhanizmy motivatsii [Psychological mechanisms of motivation]. Moskva : Izdatelstvo Moskovskogo universiteta [in Russian].

Yeretskii, M. I. (1988). Sovershenstvovaniie obucheniia v tekhnikume [Improving the process of education in college]. Moskva : Vysshaia shkola [in Russian].

Ingenkamp, K. (1991). Pedagogicheskaia diagnostika [Pedagogical diagnostics]. Moskva : Pedagogika [in Russian].

Klarin, M. V. (1989). Pedagogicheskaia tekhnologiia $v$ uchebnom protsesse: analiz zarubezhnogo opyta [Pedagogical technology in the educational process: the analysis of foreign experience]. Moskva : Znaniie [in Russian].

Kudriavtsev, V. T. (1991). Problemnoie obucheniie: istoki, sushchnost, struktura, perspektivy [Problematic education: origin, essence, structure, prospects]. Moskva : Znaniie [in Russian].

(C) Khupavtseva Nataliia

DOI (article): https://doi.org/10.32626/2227-6246.2020-49.363-385 
Levitan, K. M. (1991). Lichnost pedagoga: stanovleniie i razvitie [The personality of a teacher: formation and development]. Saratov : Izdatelstvo Saratovskogo universiteta [in Russian].

Lerner, I. Ya. (1996). Razvivaiushcheie obucheniie s didakticheskikh pozitsii [Teaching from didactic positions]. Pedagogika - Pedagogics, 2, 7-11 [in Russian].

Maksymenko, S., Tkach, B., Lytvynchuk, L., \& Onufriieva, L. (2019). Neiropsykholinhvistychne doslidzhennia politychnykh hasel iz zovnishnoi reklamy [A neuropsycholinguistic research of political slogans from outdoor advertising]. Psycholinguistics. Psykholinhvistyka. Psikholingvistika - Psycholinguistics. Psycholinguistics. Psycholinguistics, 26 (1), 246-264. Retrieved from https://psycholing-journal. com/index.php/journal/article/view/715 [in Ukrainian].

Malshtein, L. K. (1991). Formy aktivnogo obucheniia [Active Training Forms ]. Sverdlovsk : SIPI [in Russian].

Martene, R. (1979). Sotsialnaia psikhologiia $i$ sport [Social Psychology and Sports]. Moskva : Fizkultura i sport [in Russian].

Makhmutov, M. I. (1972). Teoriia i praktika problemnogo obucheniia [Theory and practice of problem education]. Kazan : Tatknigoizdat [in Russian].

Mescon, M. H. (1994). Osnovy menedzhmenta [Management basics]. Moskva : Delo LTD [in Russian].

Nain, A. Ya. (1990). Obucheniie kak upravliaiemyi protsess [Learning as a Guided Process ]. Cheliabinsk : Cheliabinskii gosydarstvennyi institut fizicheskoi kultury [in Russian].

Orlov, A. B. (1994). Fasilitator i gruppa: ot personalnogo k transpersonalnomu obshcheniiu [Facilitator and group: from personal to transpersonal communication]. Moskovskii psikhoterapevticheskii zhurnal Moscow Psychotherapeutic Journal, 2, 8-13 [in Russian].

Rogers, K. R. (1984). Empatiia. Psikhologiia emotsii. Teksty [Empathy. Psychology of emotions. Texts], (pp. 234-238). Moskva : MGU [in Russian].

Feigenberg, I. M. (1981). Problemnyie situatsii $i$ razvitiie aktivnosti lichnosti [Problem situations and the development of the activity of the personality]. Moskva : Znaniie [in Russian].

Zajonc, R., \& Sales, S. (1966). Social facilitation of dominant and subordinate responses. Journal of Experimental Social Psychology, 2, 160-168.

Zajonc, R. (1965). Social facilitation. New York : Science.

(C) Khupavtseva Nataliia

DOI (article): https://doi.org/10.32626/2227-6246.2020-49.363-385 
Хупавцева Наталія. Вплив особистісних чинників на процес фасилітативної взаємодії

\section{АНОТАЦІЯ}

Мета статmі - розкрити особистісні чинники фрасилітативної взаємодіï, що найбільшою мірою ерективно впливають на успішність реалізації діяльності суб'єкта взагалі та пізнавальної діяльності зокрема.

Для розв'язання поставлених у роботі завдань використано такі теоретичні методи дослідження: категоріальний, структурно-функціональний, аналіз, систематизація, моделювання, узагальнення.

Результати дослідження. Доведено, що певні непорозуміння у сприйнятті завдання або задачі є основним чинником, що впливає на фрасилітативну взаємодію. Іншим чинником, який може опосередковано зумовити ефект присутності сторонніх спостерігачів, є стан збудження, у якому перебуває людина на момент виконання певного завдання або задачі. Зазначено, що досить сильний рівень збудження суттєво знижується у присутності сторонніх, а слабкий рівень, навпаки, посилюється. Отже, присутність сторонніх осіб, як правило, полегшує виконання простого завдання і погіршує розв'язання складного, не зрозумілого або не опанованого суб'єктом. Інший чинник, який треба брати до уваги, - че взаємозв'язок між порушенням, викликаним присутністю спостерігачів або учасників спільної діяльності, й виконанням чієї діяльності, що вимагає чіткої координації рухів або неабияких зусиль із боку особистості.

Визначено навички "емотивного викладання", які можна назвати техніками педагогічної фасилітації (базуються на емпатії, повазі, щирості): 1) педагог ігнорує емочійні прояви своїх учнів, викликаючи тим самим їх агресію; висловлювання педагога, як правило, не відповідають почуттям, вони не є щирими, за винятком окремих випадків, коли вони засуджують і звинувачують школярів; 2) педагог реагує не на справжні почуття учня, а на ті, які він сам йому навіює; у власних висловлюваннях він лише інколи буває щирим, але позитивні емоції намагається не виявляти; 3) педагог реагує лише на поверхневі почуття учня, але робить че досить точно і часто; не боїться висловлювати як позитивні, так і негативні почуття, але не підтверджує це вголос, висловлює свої почуття у невербальний спосіб; 4) педагог реагує на приховані, глибинні почуття кожного учня, тим самим допомагаючи школярам усвідомити, чому вони відчувають саме те, що вони відчувають; дає щиру реакцію як на вер(c) Khupavtseva Nataliia

DOI (article): https://doi.org/10.32626/2227-6246.2020-49.363-385 
бальному, так і на невербальному рівні, як позитивну, так і негативну оцінку, при цьому негативна оцінка жодним чином не принижує почуття власної гідності учня.

Висновок. Виокремлено такі особистісні чинники, які зумовлюють ефрективність здійснення фасилітативної взаємодії: помірний рівень тривожності особистості; неповне (часткове) розуміння сформульованого вчителем завдання або задачі; середній рівень нервового збудження, який сприяє прийняттю фасилітативної взаємодії у процесі виконання діяльності; емотивна презентація контексту завдання або задачі чи емотивне викладання навчального матеріалу в разі здійснення педагогічної фрасилітації; компресування сфрери авторитетного впливу дорослих; взаєморозуміння учасників фасилітативної взаємодії; взаємне прийняття індивідуальних психологічних властивостей один одного; уміння поставити себе на місце інших, ідентифрікуватися з ними; довіра до учасників фасилітативної взаємодії; актуалізація суб'єктності особистості (у цьому випадку неабияку роль відіграють суб'єктивні параметри особистості педагога, які осмислюються й обов'язково враховуються учнями); формування значущого психологічного статусу особистості.

Ключові слова: фасилітативна взаємодія, особистісні чинники, тривожність, розуміння завдання або задачі, нервове збудження, емотивна презентація контексту, індивідуальні психологічні властивості.

Хупавцева Наталья. Влияние личностных факторов на процесс фасилитативного взаимодействия

\section{АННОТАЦИЯ}

Цель статьи - обосновать личностные факторы фрасилитативного взаимодействия, которые в наибольшей степени эффрективно влияют на успешность реализации деятельности субъекта вообще и познавательной деятельности в частности.

Для решения поставленных в работе задач использованы следующие теоретические методы исследования: категориальный, структурно-функциональный анализ, систематизация, моделирование, обобщение.

Результаты исследования. Доказано, что неопределенность в восприятии задачи или задания есть основным фактором, влияющим на фасилитативное взаимодействие. Другим фактором, который может (C) Khupavtseva Nataliia DOI (article): https://doi.org/10.32626/2227-6246.2020-49.363-385 
косвенно актуализировать эффект присутствия посторонних наблюдателей, является состояние возбуждения, в котором находится человек на момент выполнения данной задачи или задания. Указано, что достаточно сильный уровень возбуждения существенно снижается в присутствии посторонних людей, а слабый уровень, наоборот, усиливается. Итак, присутствие посторонних, как правило, в большей степени облегчает выполнение простой задачи и ухудшает решение сложной, непонятной либо не освоенной субъектом. Другой фрактор, который надо учитывать, - это взаимосвязь между нарушением, вызванным присутствием наблюдателей или участников совместной деятельности, $u$ выполнением этой деятельности, требующей четкой координации движений или значительных усилий со стороны личности.

Определены навыки "эмотивного преподавания», которые можно назвать техниками педагогической фасилитации (базируются на эмпатии, уважении, искренности): 1) педагог игнорирует эмоциональные проявления своих учеников, вызывая тем самым их агрессию; высказывания педагога, как правило, не являются истинными, за исключением отдельных случаев, когда они осуждают или обвиняют школьников; 2) педагог реагирует не на настоящие чувства ученика, а на те, которые он сам ему внушает; в собственных высказываниях он только иногда бывает искренним, но положительные эмоции старается не проявлять; 3) педагог реагирует только на поверхностные чувства ученика, но делает это достаточно точно и часто; не боится высказывать как положительные, так и отрицательные чувства, но не подтверждает это вслух, а выражает свои чувства невербально; 4) педагог реагирует на скрытые, глубинные чувства кандого ученика, помогая школьникам тем самым понять, почему они чувствует то, что именно они чувствуют; дает истинную реакцию как на вербальном, так и на невербальном уровне, как положительную, так и отрицательную оценку, при этом отрицательная оценка никоим образом не унижает чувство собственного достоинства ученика.

Вывод. Выделены следующие личностные факторы, которые обуславливают эфрфективность осуществления фасилитативного взаимодействия: умеренный уровень тревожности личности; неполное (частичное) понимание срормулированной учителем задачи или задания; средний уровень нервного возбуждения, который способствует принятию фасилитативного взаимодействия в процессе выполнения C Khupavtseva Nataliia

DOI (article): https://doi.org/10.32626/2227-6246.2020-49.363-385 
DOI: https://doi.org/10.32626/2227-6246.2020-49 2020. ВиПУСК 49

деятельности; эмотивная презентация контекста задачи или задания или эмотивное преподавание учебного материала при актуализации педагогической фасилитации; компрессирование сферы авторитетного влияния взрослых; взаимопонимание участников фасилитативного взаимодействия; взаимное принятие индивидуальных психологических свойств друг друга; умение поставить себя на место других, идентифицироваться с ними, доверие к участникам фасилитативного взаимодействия; актуализация субъектности личности (в данном случае большую роль играют субъективные параметры личности педагога, которые осмысливаются и обязательно учитываются учениками); формирование существенного психологического статуса личности.

Ключевые слова: фасилитативное взаимодействие, личностные факторы, тревожность, понимание задачи или задания, нервное возбуждение, эмотивная презентация контекста, индивидуальные психологические свойства.

Original manuscript received April 15, 2020

Revised manuscript accepted May 26, 2020

(C) Khupavtseva Nataliia

DOI (article): https://doi.org/10.32626/2227-6246.2020-49.363-385 